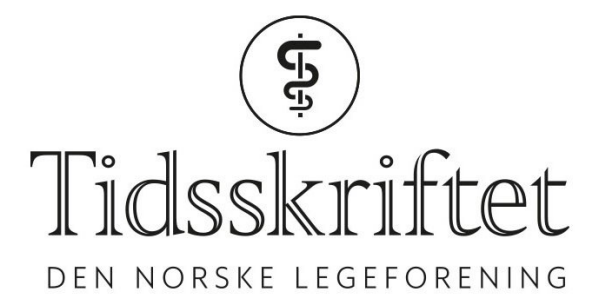

\title{
Operasjon er bra - men ikke alltid best
}

KOMMENTAR

\section{BENEDICTE SKJOLD- ØDEGAARD}

E-post: benedicte.skjold-odegaard@helse-fonna.no Benedicte Skjold- $\emptyset$ degaard er overlege og ph.d.-stipendiat. Forfatteren har ikke oppgitt noen interessekonflikter.

I Tidsskriftet nr. 1/2021 uttaler professor Hartwig Körner seg om en studien av behandling ved akutt appendisitt (1). Jeg deler professor Körners oppfatning om at den omtalte studien (2) i seg selv ikke gir grunnlag for endring av praksis. Jeg synes imidlertid at det er verdt å merke seg at det i den siste oppdateringen av World Society of Emergency Surgery fra 2020 (3) anbefales at en konservativ tilnærming diskuteres med alle pasienter som har en ukomplisert appendisitt med fravær av appendikolitt.

I den siste PasOpp-undersøkelsen (nasjonal brukererfaringsundersøkelse) fra 2019 (4) angir $68 \%$ av pasientene at de opplevde at legene de møtte var i stor grad eller i svært stor grad interessert i deres beskrivelse av egen situasjon. 82 \% opplevde at behandlingen var i stor grad eller i svært stor grad tilpasset deres situasjon. Som leger må vi i stadig økende grad forholde oss til at vi blir målt på pasienttilfredshet - og vi må også forholde oss til Pasientog brukerrettighetsloven der vi som leger er forpliktet til å involvere pasienter i valg mellom tilgjengelige behandlingsvalg.

En annen viktig faktor er bruk av operasjonskapasitet. Spesielt på mindre sykehus er det gjerne kun ett operasjonsteam tilstede på kveldstid og nattestid. Da vil operasjon av en ukomplisert akutt appendisitt samtidig kunne føre til at et annet inngrep utsettes - kanskje med økt morbiditet og i verste fall mortalitet som resultat. Vi er som leger satt til å forvalte betydelige ressurser - og her må den samlede ressursbruken has i mente hos pasienter der det finnes likeverdige behandlingsvalg.

Operasjon for akutt appendisitt har tradisjonelt vært en av de første inngrepene en fersk LIS får gjøre, og det er vist at LIS kan utføre appendektomier trygt og uten fare for pasienten (5). Man skal derfor ikke undervurdere viktigheten av disse inngrepene for kirurgers utdannelse. Med stadig flere LIS fordelt på et begrenset antall inngrep, og oppdelte vaktdøgn som et resultat av arbeidstidsbestemmelser er det økende frykt for at dagens LIS ikke får tilstrekkelig operativ erfaring. Dette er et viktig moment - men som ikke kan være avgjørende.

Jeg ønsker med dette å understreke at det ved ukomplisert akutt appendisitt uten tilstedeværelse av appendikolitt finnes to likeverdige behandlingsvalg - og kirurgens preferanse kan ikke være overordnet pasientens ønske og de tilgjengelige ressurser. 
LITTERATUR:

1. Skodvin T. Operasjon er fortsatt best ved akutt appendisitt. Tidsskr Nor Legeforen 2021; 141. doi: 10.4045/tidsskr.20.0897. [CrossRef]

2. Flum DR, Davidson GH, Monsell SE et al. A Randomized Trial Comparing Antibiotics with Appendectomy for Appendicitis. N Engl J Med 2020;383: 1907-19. [PubMed][CrossRef]

3. Di Saverio S, Podda M, De Simone B et al. Diagnosis and treatment of acute appendicitis: 2020 update of the WSES Jerusalem guidelines. World J Emerg Surg 2020; 15: 27. [PubMed][CrossRef]

4. Sjetne IS. Holmboe, Olaf. Pasienters erfaringer med norske sykehus i 2019. Oslo:

Folkehelseinstituttet, 2020.

5. Barrett JR, Drezdzon MK, Monawer AH et al. Safety in Allowing Residents to Independently Perform Appendectomy: A Retrospective Review. J Am Coll Surg 2019; 229: 621-5. [PubMed][CrossRef]

Publisert: 8. mars 2021. Tidsskr Nor Legeforen. DOI: 10.4045/tidsskr.21.0120

(C) Tidsskrift for Den norske legeforening 2020. Lastet ned fra tidsskriftet.no 